\title{
Peran Penyuluh Agama Islam Non PNS Bidang Perkawinan dalam Upaya Membina Keluarga Sakinah (Studi di KUA Kecamatan Panceng Kabupaten Gresik)
}

\author{
Karmuji, Nofan Andrian Usmani Putra \\ Institut Pesantren Sunan Drajat Lamongan \\ E-mail: karmuji@insud.ac.id, novanusman4@gmail.com
}

\begin{abstract}
Abstrak: Keluarga sakinah adalah keluarga yang penuh dengan kecintaan dan rahmat Allah SWT. Tidak ada satupun pasangan suami istri yang tidak mendambakan keluarganya bahagia. Akan tetapi, untuk memperoleh gelar sakinah tersebut tidaklah sangat mudah layaknya membalik telapak tangan, sebab dalam mengarungi rumah tangga pasti banyak sekali problem-problem yang menghambat, baik dibidang ekonomi maupun sosial, material ataupun inmaterial. Melihat hal tersebut, sudah pasti seorang pasangan suami istri membutuhkan yang namanya sebuah bimbingan atau pendidikan pengetahuan tentang konsep berumah tangga agar tercapailah keluarga sakinah tersebut, terutama bagi pasangan suami istri yang notabennya kurang bahkan tidak mengetahui sama sekali cara hidup berumah tangga. Dalam hal ini lembaga yang berwenang terhadap hal-hal yang berkaitan dengan suatu pernikahan adalah KUA (Kantor Urusan Agama), sebab KUA merupakan lembaga yang pertama kali mengesahkan secara hukum terjadinya suatu pernikahan, baik sah dalam kaca mata hukum Islam maupun hukum umum (Undang-undang). Dan tugas tersebut dalam struktur KUA adalah tugas dari Penyuluh Agama Islam Non PNS Bidang Perkawinan. Hasil penelitian menunjukan bahwa peran Penyuluh Agama Islam Non PNS Bidang Perkawinan adalah sebagai konsultan dalam menyelesaikan masalah dan sebagai corong Kementerian Agama dalam mensyi'arkan ajaran agama terutama dalam hal membangun keluarga yang sakinah. Berdasarkan temuan ini dapat disimpulkan bahwa peran Penyuluh Agama Islam Non PNS Bidang Perkawinan masih belum optimal dan memberikan dampak, sebab masih minimnya fasilitas dalam proses penyuluhan dan angka perceraian tidak mengalami penurunan.

Kata kunci: Peran penyuluh agama, membina, keluarga sakinah.
\end{abstract}

\section{Pendahuluan}

Manusia secara fitrah atau natural diciptakan Tuhan dalam dirinya mempunyai kebutuhan-kebutuhan jasmani, diantaranya kebutuhan 
seksual yang akan dipenuhi dengan baik dan teratur dalam hidup berkeluarga ${ }^{1}$. Meski demikian, Allah SWT tidak menjadikan manusia seperti makhluk lainnya yang menyalurkan nalurinya dengan bebas, menuruti hawa nafsu dengan sesuka hati dan mengikuti ajakan syetan sehingga terjerumus pada perbuatan yang tidak halal berupa sikap-sikap yang merusak dan menimbulkan dosa-dosa. Akan tetapi, untuk menjaga kehormatan dan martabat manusia maka Allah SWT mengadakan hukum yang sesuai dengan kehormatan dan martabat tersebut. Dalam arti lain hubungan antara laki-laki dan perempuan diatur secara terhormat dalam sebuah ikatan pernikahan.

Allah SWT menciptakan manusia dengan berpasangan, laki-laki dan wanita. Perbedaan penciptaan ini bukan dimaksudkan untuk menegaskan kelebihan yang satu dengan yang lainnya. Akan tetapi, adanya hal yang demikian itu agar jenis yang satu dengan yang lain (laki-laki dan wanita) dapat menjalin kesatuan dalam misi yang sama sebagai hamba dan khalifah-Nya di muka bumi ini².

Keluarga sakinah adalah keluarga yang penuh dengan kecintaan dan rahmat Allah SWT. Tidak ada satupun pasangan suami istri yang tidak mendambakan keluarganya bahagia. Akan tetapi, untuk memperoleh gelar sakinah tersebut tidaklah sangat mudah layaknya membalik telapak tangan, sebab dalam mengarungi rumah tangga pasti banyak sekali problem-problem yang menghambat, baik dibidang ekonomi maupun sosial, material ataupun inmaterial.

Melihat hal tersebut, sudah pasti seorang pasangan suami istri membutuhkan yang namanya sebuah bimbingan atau pendidikan pengetahuan tentang konsep berumah tangga agar tercapailah keluarga sakinah tersebut, terutama bagi pasangan suami istri yang notabennya kurang bahkan tidak mengetahui sama sekali cara hidup berumah tangga. Dalam hal ini lembaga yang berwenang terhadap hal-hal yang berkaitan dengan suatu pernikahan adalah KUA (Kantor Urusan Agama), sebab KUA merupakan lembaga yang pertama kali mengesahkan secara hukum terjadinya suatu pernikahan, baik sah dalam kaca mata hukum Islam maupun hukum umum (Undang-undang).

\footnotetext{
${ }^{1}$ Harun Nasution, Islam Rasional ; Gagasan dan Pemikiran, (Bandung: Mizan, 1998), hlm. 434.

${ }^{2}$ Abdul Syukur Al-Azizi, Sakinah Mawaddah wa Rahmah ; Tuntunan Lengkap Menggapai Baiti Jannati di dalam Rumah, (Yogyakarta: Diva Press, 2017), hlm. 22.
} 
Tugas utama KUA dalam Pasal 2 PMA No. 34 Tahun 2016 adalah melaksanakan pelayanan dan bimbingan masyarakat Islam di wilayah kerjanya yaitu Kecamatan. Dalam aturan tersebut juga mengatur tentang struktur kepengurusan dan tugasnya masing-masing. Diantara srukturstruktur kepengurusan tersebut ada yang namanya kelompok Jabatan Fungsional.

Kelompok tersebut terdiri dari kelompok Jabatan Fungsional Tertentu (JFT) dan Jabatan Fungsional Umum (JFU) ${ }^{3}$. Dalam kelompok Jabatan Fungsional Tertentu (JFT) itu sendiri terdiri dari Penghulu dan Penyuluh Agama Islam. Pada dasarnya Penyuluh Agama Islam terbagi menjadi dua kategori, yaitu Penyuluh Agama Islam Fungsional (PNS) dan Penyuluh Agama Islam Non PNS. Akan tetapi dalam penelitian ini, peneliti tidak akan memaparkan hal-hal yang tidak ada kaitannya dengan Penyuluh Agama Islam Non PNS, sebab yang ingin dikaji dan diteliti oleh peneliti adalah hal-hal yang ada kaitannya dengan fungsi, tugas, dan peran dari Penyuluh Agama Islam Non PNS.

Dalam Keputusan Direktur Jendral Bimbingan Masyarakat Islam (Dirjen Bimas) Nomor 298 tahun 2017 tentang Pedoman Penyuluh Agama Islam Non PNS yang dimaksud dengan Penyuluh Agama Islam Non PNS adalah Penyuluh Agama Islam honorer yang diangkat dengan Surat Keputusan Kepala Kantor Kementerian Agama Kab/Kota.

Penyuluh Agama Islam Non PNS adalah pegawai pemerintah dengan perjanjian kinerja yang diangkat, ditetapkan dan diberi tugas, tanggungjawab serta wewenang secara penuh untuk melakukan kegiatan bimbingan, penyuluhan melalui bahasa agama dan pembangunan pada masyarakat melalui Surat Keputusan Kepala Kantor Kementerian Agama Kabupaten/Kota. Dalam usaha mengimplementasikan wewenang dan hak di atas, maka Penyuluh Agama Islam Non PNS merupakan salah satu bentuk satuan kegiatan yang memiliki nilai strategis, khususnya dalam menjalankan fungsi memperlancar pelaksanaan pembangunan dibidang keagamaan.

Kehadiran Penyuluh Agama Islam Non PNS ini membawa perubahan yang sangat signifikan, sebab mereka merupakan salah satu alat pembantu dalam membimbing ummat manusia terutama yang beragama Islam dengan melalui pendekatan langsung dengan para masyarakat yang

3 PMA No. 34 Tahun 2016 Tentang Organisasi dan Tata Kerja Kantor Urusan Agama Kecamatan, Pasal 11. 
menjadi wilayah binaannya, dalam artian lain bahwa Penyuluh Agama Islam Non PNS adalah corong dari Menteri Agama dalam menjalankan tugasnya.

Penyuluh Agama Islam Non PNS dalam menjalankan tugasnya bertanggung jawab penuh kepada Kepala KUA yang ada di wilayah kecamatannya masing-masing. Sejauh ini Penyuluh Agama masih dihadapkan pada sejumlah problem, sejumlah problem dalam program dalam lingkungan masyarakat dimana Penyuluh Agama sebagai salah seorang motivator dalam setiap acara keagamaan dewasa ini tidak menunjukan peran yang diharapkan, hal tersebut dapat dilihat pada berbagai kasus yang ada seperti perceraian sebab kegagalan membina rumah tangga bukan saja membahayakan rumah tangga itu sendiri, tetapi juga sangat berpengaruh kepada kehidupan masyarakat, disuatu masyarakat yang banyak terjadinya perceraian merupakan ukuran kondisi dari masyarakat tersebut ${ }^{4}$.

Kemudian ada yang namanya kelompok Jabatan Fungsional Umum (JFU) yang masing-masing terbagi dalam beberapa kelompok sesuai dengan bidang keahliannya berdasarkan ketentuan peraturan perundangundangan. Karena yang menjadi perbincangan peneliti adalah mengenai perkawinan dan keluarga sakinah, maka yang bertugas menangani permasalahan tersebut adalah Penyuluh Agama Islam, lebih spesifiknya lagi adalah tugas bagi Penyuluh Perkawinan dan Keluarga Sakinah, yang mana tugas utamanya adalah sesuai namnaya yaitu memberikan penyuluhan berupa bimbingan mengenai perkawinan dan cara membentuk keluarga sakinah serta membantu masyarakat dalam menyelesaikan permasalahan yang ada kaitannya dengan perkawinan.

Penyuluh Agama Islam Non PNS dengan spesialisasi keluarga sakinah, harus menguasai fiqih munakahat, ayat-ayat dan hadits tentang perkawinan dan keluarga, UU Nomor 1 Tahun 1974 Tentang Perkawinan, dan Kompilasi Hukum Islam. Sesuai yang tercantum dalam draf buku pedoman Penyuluh Agama Islam Non PNS bidang perkawinan dan keluarga sakinah berkoordinasi dengan penyuluh Agama Fungsional untuk membuat mapping kegiatan dan peta dakwah di wilayah sasaran kerjanya atau daerah binaannya dengan materi atau bahan penyuluhan yang ada kaitannya sesui dengan bidangnya, yaitu :

${ }^{4}$ Abdul Manan, Aneka Masalah Hukum Perdata Islam di Indonesia, (Jakarta : Kencana, 2006), hlm. 8 
1. Membuat program pembinaan/ kursus pra nikah;

2. Pengertian keluarga sakinah;

3. Membangun rumahtangga dengan Al-Qur'an dan Sunnah Nabi;

4. Membangun rumahtangga dengan kasih sayang;

5. Mengelola konflik dalam rumah tangga;

6. Menyiapkan keturunan yang sholeh/sholehah;

7. Menyiapkan generasi yang tangguh;

8. Memahami hak dan kewajiban suami istri;

9. Melakukan evalusi kegiatan.

Dari uraian tersebut sehingga menarik bagi peneliti untuk mengkaji bagaimana pengaruh adanya Penyuluh Agama Islam Non PNS bidang perkawinan dalam membina suatu keluarga agar tujuan dari adanya perkawinan tercapai yaitu membentuk keluarga sakinah, mawaddah, dan rahmah.

\section{Metode Penelitian}

Metode penelitian yang digunakan dalam penelitian ini adalah metode penelitian dengan menggunakan pendekatan kualitatif, dimana penelitian yang dilakukan bersifat deskriptif yaitu penelitian yang dilakukan untuk mengetahui atau menggambarkan kenyataan dari kejadian yang diteliti atau penelitian yang dilakukan terhadap variabel mandiri atau tunggal, yaitu tanpa membuat perbandingan atau menghubungkan dengan variabel lain. Selain itu, penelitian deskriptif juga terbatas pada usaha mengungkapkan suatu masalah, keadaan atau peristiwa sebagaimana adanya, sehingga bersifat sekedar untuk mengungkapkan fakta dan memberikan gambaran secara obyektif tentang keadaan sebenarnya dari obyek yang diteliti.

\section{Pengertian Penyuluh Agama Islam Non PNS}

Secara bahasa "penyuluh" merupakan arti dari kata Bahasa Inggris "counseling", yang sering diterjemahkan dengan "menganjurkan atau menasehatkan"5. Di lingkungan Kementerian Agama, ada namanya Penyuluh Agama pada Kantor Urusan Agama (KUA) yang bertempat di wilayah Kecamatan. Kata "penyuluh" di sini, mengandung arti“penerangan", maksudnya Penyuluh Agama memiliki tugas dan kewajiban menerangkan segala sesuatu yang berkaitan dengan agama, hukum halal haram, cara, syarat dan rukun dari suatu pelaksanaan ritual

${ }^{5}$ Departemen Pendidikan Nasional, Kamus Besar Bahasa Indonesia.....hlm. 357. 
tertentu, pernikahan, zakat, keluarga sakinah, kemasjidan dan lain sebagainya ${ }^{6}$.

Adapun yang dimaksud dengan Penyuluh Agama sebagaimana tercantum dalam Keputusan Menteri Agama RI Nomor 791 tahun 1985, adalah : Pembimbing umat Islam dalam rangka pembinaan mental, moral dan ketaqwaan kepada Tuhan Yang Maha Esa, Allah SWT, serta menjabarkan segala aspek pembangunan melalui pintu dan bahasa agama ${ }^{7}$.

Sedangkan dalam Keputusan Direktur Jendral Bimbingan Masyarakat Islam (Dirjen Bimas) Nomor 298 tahun 2017 tentang Pedoman Penyuluh Agama Islam Non PNS yang dimaksud dengan Penyuluh Agama Islam Non PNS adalah Penyuluh Agama Islam honorer yang diangkat dengan surat Keputusan Kepala Kantor Kementerian Agama Kab/Kota.

Penyuluh Agama Islam Non PNS adalah seseorang yang diberi tugas, tanggungjawab, wewenang dan hak untuk melaksanakan kegiatan bimbingan dan Penyuluhan dibidang keagamaan Islam dan pembangunan melalui bahasa agama.

Dengan demikian, Penyuluh Agama Islam adalah para juru penerang penyampai pesan bagi masyarakat mengenai prinsip-prinsip dan etika nilai keberagamaan yang baik. Selain itu, Penyuluh Agama Islam merupakan ujung tombak dari Kementerian Agama dalam pelaksanaan tugas membimbing umat Islam dalam mencapai kehidupan yang bermutu dan sejahtera lahir bathin. Dan hasil akhir yang ingin dicapai, pada hakekatnya ialah terwujudnya kehidupan masyarakat yang memiliki pemahaman mengenai agamanya secara memadai yang ditunjukkan melalui pengamalannya yang penuh komitmen dan konsisten seraya disertai wawasan multi kultural untuk mewujudkan tatanan kehidupan yang harmonis dan saling menghargai satu sama lain ${ }^{8}$.

Sebagai landasan hukum keberadaan Penyuluh Agama Islam Non PNS adalah :

1. Peraturan Menteri Agama (PMA) Nomor 34 Tahun 2016 tentang Organisasi dan Tata Kerja KUA Kecamatan dalam hal penempatan Jabatan Fungsional Penyuluh Agama Islam.

\footnotetext{
${ }^{6}$ Darwan, Pengantar Bimbingan Konseling, (Jakarta : Rineka Cipta, 2010), hlm. 15

${ }^{7}$ Depag, Buku Panduan Pelaksanaan Tugas Penyuluhan Agama, (Jakarta : 2003), hlm. 37.

${ }^{8}$ Kemenag, Keputusan Direktur Jendral Bimbingan Masyarakat Islam Nomor 298 Tahun 2017

Tentang Pedoman Penyuluh Agama Islam Non PNS, (Jakarta : Kemenag, 2017), hlm. 14.
} 
2. Keputusan Menteri Agama (KMA) Nomor 164 Tahun 1996 Jo. Nomor 776 Tahun 2016 tentang Honorarium Penyuluh Agama Non PNS.

3. Keputusan Dirjen Bimas Islam Nomor DJ.III/342/Tahun 2016 tentang Petunjuk Teknis Pengangkatan Penyuluh Agama Islam Non PNS.

4. Surat Dirjen Bimas Islam Nomor B.2262 tanggal 6 September 2016 tentang Pedoman Rekrutmen Penyuluh Agama Islam Non PNS Tahun 2016.

5. Keputusan Direktur Jendral Bimbingan Masyarakat Islam Nomor 298 tahun 2017 tentang Pedoman Penyuluh Agama Islam Non PNS.

\section{Peranan Penyuluh Agama Islam Non PNS}

Tugas Penyuluh Agama Islam tidak semata-mata melaksanakan penyuluhan agama dalam arti sempit berupa pengajian saja, akan tetapi keseluruhan kegiatan penerangan baik berupa bimbingan dan penerangan tentang berbagai program pembangunan. Ia berperan sebagai pembimbing umat dengan rasa tanggung jawab, membawa masyarakat kepada kehidupan yang aman dan sejahtera.

Posisi Penyuluh Agama Islam ini sangat strategis baik untuk menyampaikan misi keagamaan maupun misi pembangunan. Penyuluh Agama Islam juga sebagai tokoh panutan, tempat bertanya dan tempat mengadu bagi masyarakatnya untuk memecahkan dan menyelesaikan berbagai masalah yang dihadapi oleh umat Islam.

Apalagi seiring dengan perkembangan ilmu pengetahuan dan teknologi, maka tantangan tugas Penyuluh Agama Islam semakin berat, karena dalam kenyataan kehidupan ditataran masyarakat mengalami perubahan pola hidup yang menonjol. Menurut Fauzie Nurdin peranan penting dari Penyuluh Agama adalah selain sebagai figur juga berperan sebagai pemimpin masyarakat, Penyuluh Agama juga sebagai agent of change, sebagai ujung tombak Kementerian Agama.

1. Fungsi Penyuluh Agama Islam

Tugas pokok Penyuluh Agama Islam adalah melakukan dan mengembangkan kegiatan bimbingan atau penyuluhan agama dan pembangunan melalui bahasa agama. Sedangkan fungsi dari Penyuluh Agama menyangkut fungsi informatif dan edukatif, fungsi konsultatif, dan advokatif 9 .

2. Faktor Kendala yang Dihadapi Penyuluh Agama Islam dalam Proses Penyuluhan.

${ }_{9}^{9}$ Depag, Panduan Tugas Operasional Penyuluhan Agama Islam....., hlm.152 
Sebuah program tidak terlepas dari faktor pendukung dan faktor penghambat. Hambatan sekecil apapun bentuknya yang ada dalam suatu organisasi, pasti akan mempengaruhi serta merugikan organisasi tersebut karena pelaksanaan kegiatan dalam rangka pencapaian tujuan organisasi akan terhambat. Mengakibatkan gagalnya pencapaian tujuan yang telah ditetapkan dalam dasar-dasar keorganisasiannya.

\section{Peran Penyuluh Agama Islam Non PNS Bidang Perkawinan dalam Membina Keluarga Sakinah.}

Pernikahan adalah momentum yang sangat penting bagi perjalanan hidup manuisia. Setelah pernikahan, kedua belah pihak akan menerima beban yang sangat barat dan tanggung jawab sesuai kodrat masingmasing. Tanggung jawab dan beban itu bukanlah suatu yang mudah untuk dilakukan, sehingga mereka harus mampu melaksanakannya sebagai seorang suami maupun istri. Untuk itulah perlu kiranya sepasang suami istri, lebih-lebih calon pengantin mengetahui cara-cara bagaimana membentuk keluarga sakinah dan harmonis, dan hal ini sangat diperhatikan oleh beberapa KUA untuk memberikan pembekalan pernikahan terutama KUA Kecamatan Panceng ${ }^{10}$.

Adapun peran yang dilakukan oleh Penyuluh Agama Islam Non PNS KUA Kecamatan Panceng adalah sebagai berikut :

1) Penyuluh Agama sebagai figure juga berperan sebagai pemimpin masyarakat.

Maksud dari peran ini adalah Penyuluh Agama sebagai imam atau pemimpin dalam masalah agama dan masalah kemasyarakatan. Hal ini sesuai dengan yang sudah dilakukan oleh Penyuluh Agama Islam Non PNS Bidang Perkawinan KUA Kecaman Panceng yaitu membantu masyarakat yang ada dalam wilayah binaannya dalam memecahkan masalah yang ada hubungannya dengan perkawinan.

Adapun peran yang dilakukan oleh Penyuluh Agama Islam Non PNS Bidang Perkawinan KUA Kecaman Panceng yaitu sebagai figure serta pemimpin masyarakat adalah antara lain sebagai berikut:

- Menjadi penengah ketika ada masalah keluarga yang ada di wilayah binaannya.

10 Abdullah Hanif, Wawancara, Penyuluh Agama Islam Non PNS Bidang Perkawinan dan Keluarga Sakinah (Panceng : Selasa, 17 Juli 2018). 
- Menjadi pelopor kegiatan keagamaan, seperti mengadakan jama'ah istighosah dan tahlil, pengajian umum, memberikan khutbah jum'at, dan sejenisnya.

2) Penyuluh Agama sebagai agent of change.

Dalam peran ini, tugas Penyuluh Agama Islam Non PNS Bidang Perkawinan KUA Kecaman Panceng adalah menjadi remote cotrol, artinya Penyuluh Agama sebagai kunci perubahan masyarakat yang ada di wilayah binaannya. Dari yang dulu tidak tahu cara-cara berumahtangga menjadi tahu, dll. Hal itu dilakukan oleh Penyuluh Agama Islam Non PNS Bidang Perkawinan KUA Kecaman Panceng melalui beberapa kegiatan diantaranya yaitu : melakukan pembinaan ke masyarakat binaannya, membuat majlis ta'lim yang di dalamnya ada ceramah agama, dl111.

Menurut peneliti, bahwasannya pada peran yang satu ini, Penyuluh Agama Islam Non PNS Bidang Perkawinan KUA Kecaman Panceng kurang maksimal, sebab sesuai data yang diperoleh oleh peneliti menjelaskan bahwa angka perceraian setiap tahunnya tidak mengalami penurunan. Hal tersebut disebabkan adanya Penyuluh Agama Islam Non PNS masih baru dan jumlah anggotanya dirasa kurang mengingat wilayah yang ada di Kecamata Panceng juga luas dan mempunyai jumlah penduduk yang banyak.

3) Sebagai ujung tombak Kementerian Agama.

Peran ini adalah peran yang sangat utama, karena dengan adanya Penyuluh Agama yang ada di KUA Kecamatan segala sesuatu yang ada kaitannya dengan urusan keagamaan khusunya dalam hal pernikahan yang semulanya menjadi tanggung jawab penuh Kementerian Agama dan sangat tidak mungkin jika dikerjakan sendiri oleh Kementerian Agama sebab dapat dilihat sendiri Indonesia mempunyai wilayah yang sangat luas dan jumlah masyarakat yang banyak.

Maka dengan adanya Penyuluh Agama yang ada di KUA Kecamatan sangat berperan penting untuk membantu tugas-tugas yang ada di Kementerian Agama. Adapun peran Penyuluh Agama Islam Non PNS Bidang Perkawinan yang ada di KUA Kecamatan

11 Abdullah Hanif, Wawancara, Penyuluh Agama Islam Non PNS Bidang Perkawinan dan Keluarga Sakinah (Panceng : Selasa, 17 Juli 2018). 
Panceng sebagai ujung tombak Kementerian Agama diantaranya yaitu :

- Memberi pembekalan kepada suscatin yakni khusus untuk calon pengantin yang sudah mendaftarkan dirinya di KUA yang berkehendak ingin melaksanakan pernikahan dan sebelumnya suscatin ini diberi pembekalan oleh BP4.

- Memberi pembekalan pra nikah yakni ditujukan kepada semua kalangan yang berkehendak maupun yang belum berkehendak untuk melakukan pernikahan.

- Memberi bimbingan dan penyuluhan kepada masyarakat yang ada di desa-desa wilayah Kecamatan Panceng melalui kelompok binaan-binaan atau majlis ta'lim tentang kiat-kiat membentuk keluarga sakinah ${ }^{12}$.

Upaya KUA Kecamatan Panceng dalam memberikan bimbingan dan penyuluhan tidak lain dan tidak bukan dalam rangka mencegah adanya pernikahan di bawah umur yaitu sesuai dengan UU yang berlaku di Indonesia yakni dalam Pasal 7 UUP No. 1 tahun 1974 dan KHI dalam Pasal 15 bahwa pernikahan bisa dilangsungkan sekurangkurangnya laki-laki berusia 19 tahun dan sekurang-kurangnya perempuan berusia 16 tahun.

Selain dari pada tujuan tersebut, peran dari Penyuluh Agama Islam Non PNS bidang perkawinan mengadakan bimbingan dan penyuluhan kepada masyarakat yang ada di desa-desa wilayah Kecamatan Panceng melalui kelompok binaan-binaan atau majlis ta'lim sangat membantu bagi calon pengantin lebih-lebih terhadap masyarakat yang sudah berumah tangga untuk mewujudkan rumah tangga yang sangat diimpikan, yaitu keluarga yang sakinah, mawaddah, wa rahmah dengan memberikan tausiyah/pengajian atau forum diskusi.

Menilik dari peranan Penyuluh Agama Islam Non PNS Bidang Perkawinan Kecamatan Panceng sebagaimana diuraikan tersebut di atas, maka jelas bahwa tugas pokoknya adalah melakukan dan mengembangkan kegiatan bimbingan atau penyuluhan agama dan pembangunan melalui bahasa agama. Sedangkan fungsi dari Penyuluh Agama Islam Non PNS Bidang Perkawinan Kecamatan

12 Abdullah Hanif, Wawancara, Penyuluh Agama Islam Non PNS Bidang Perkawinan dan Keluarga Sakinah (Panceng : Senin, 16 Juli 2018). 
Panceng yaitu menyangkut fungsi informatif dan edukatif, fungsi konsultatif, dan advokatif ${ }^{13}$.

Dari berbagai fungsi Penyuluh Agama Islam Non PNS Bidang Perkawinan Kecamatan Panceng di atas maka dapat diuraikan sebagai berikut :

a. Fungsi Informatif dan Edukatif.

Penyuluh Agama Islam Non PNS Bidang Perkawinan Kecamatan Panceng memposisikan dirinya sebagai da'i yang berkewajiban mendakwahkan Islam, menyampaikan penerangan agama dan mendidik masyarakat sebaik-baiknya sesuai dengan tuntunan Al-Qur'an dan Hadits.

b. Fungsi Konsultatif.

Penyuluh Agama Islam Non PNS Bidang Perkawinan Kecamatan Panceng menyediakan dirinya untuk turut memikirkan dan memecahkan persoalan-persoalan yang dihadapi masyarakat, baik persoalan-persoalan pribadi, keluarga atau persoalan masyarakat secara umum. Penyuluh Agama Islam Non PNS Bidang Perkawinan Kecamatan Panceng harus bersedia membuka mata dan telinga terhadap persoalan yang dihadapi oleh umat. Selai itu, Penyuluh Agama Islam Non PNS Bidang Perkawinan Kecamatan Panceng juga menjadi tempat bertanya dan tempat mengadu bagi masyarakat untuk memecahkan dan menyelesaikan masalah dengan nasehatnya. Maka dalam hal ini Penyuluh Agama Islam Non PNS Bidang Perkawinan Kecamatan Panceng berperan sebagai psikolog, teman curhat dan teman untuk berbagi.

c. Fungsi Advokatif.

Penyuluh Agama Islam memiliki tanggung jawab moral dan sosial untuk melakukan kegiatan pembelaan terhadap umat/masyarakat binaannya terhadap berbagai ancaman, gangguan, hambatan dan tantangan yang merugikan akidah, mengganggu ibadah dan merusak akhlak. Fungsi advokatif Penyuluh Agama selama ini memang belum mampu seluruhnya dapat diperankan oleh Penyuluh Agama, dimana banyak kasus yang terjadi di kalangan umat Islam sering tidak dapat kita bela. Misalnya dalam kasuistik yang berhubungan dengan politik,

${ }^{13}$ Depag, Panduan Tugas Operasional Penyuluhan Agama Islam....., hlm.152 
keadilan sosial (penggusuran), bahkan sampai upaya pemurtadan yang berhubungan dengan perkawinan. Sehingga persoalan yang dihadapi tidak dapat diselesaikan dengan baik. Bahkan sering seorang Penyuluh Agama tidak berdaya melihat umat Islam mendapat perlakuan yang tidak adil dari golongan lain.

Karena sasaran penyuluan agama Islam adalah kelompokkelompok masyarakat Islam yang terdiri dari berbagai latar belakang sosio cultural, maka pemetaan kelompok sasaran Penyuluh Agama Islam penting dilakukan untuk memudahkan dalam memilih metode pendekatan dan menentukan materi bimbingan atau penyuluhan yang relevan dan benar-benar dibutuhkan oleh kelompok sasaran.

Adapun tugas atau materi yang disampaikan oleh Penyuluh Agama Islam Non PNS khususnya bidang perkawinan sesuai buku pedoman kerjanya adalah sebagai berikut :

1) Membuat program pembinaan/kursus pra nikah.

2) Pengertian keluarga sakinah.

3) Membangun rumah tangga dengan al-Qur'an dan Sunnah Nabi Muhammad Saw.

4) Membangun rumah tangga dengan kasih sayang.

5) Mengelola konflik dalam rumah tangga.

6) Meyiapkan keturunan yang sholih dan sholihah.

7) Menyiapkan generasi yang tangguh.

8) Memahami hak dan kewajiban suami istri.

9) Melakukan evaluasi kegiatan ${ }^{14}$.

Menurut peneliti sendiri, upaya bimbingan dan penyuluhan yang dilakukan oleh KUA Kecamatan Panceng ini sangat bagus dan sangat berdampak baik, karena dalam hal ini pihak KUA benar-benar menjalankan amanah dari pemerintah yang tidak hanya mengabdi kepada negara dalam melayani administrasi pernikahan, selain itu juga memberi bantuan kepada masyarakat agar dapat membina keluarga yang harmonis dan mencegah terjadinya kehancuran rumah tangga.

Akan tetapi, menurut data yang peneliti dapatkan pada waktu melakukan observasi ke Kantor Kementerian Agama Kabupaten Gresik menunjukkan bahwa kinerja dari Penyuluh Agama Islam Non PNS Bidang Perkawinan kurang memberikan dampak ataupun hasil,

${ }^{14}$ Syaiful Wahid, Wawancara, Kepala KUA Kecamatan Panceng (Panceng: Rabu, 18 Juli 2018 
hal ini bisa dilihat data rekapitulasi peristiwa NTCR (Nikah, Talak, Cerai, Rujuk) yang ada di Kecamatan Panceng tidak mengalami penurunan terutama dalam hal Talak dan Cerai, bahkan di Tahun 2017 mengalami peningkatan menjadi 35 kasus yang sebelumnya hanya 10 kasus.

\section{Gambar 2}

Rekapitulasi NTCR Kecamatan Panceng Tahun 2011-2017

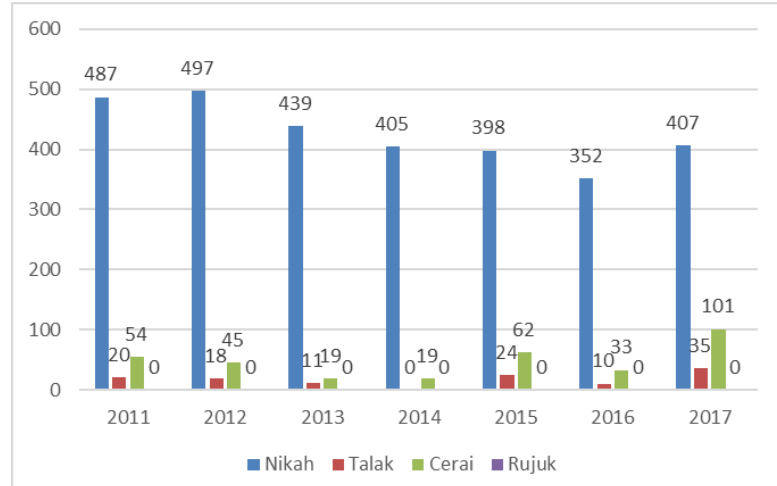

Sumber : Dokumen Kementerian Agama Kabupaten Gresik Tahun 2018

Peneliti menyimpulkan bahwa ada beberapa faktor yang menyebabkan hal itu terjadi. Diantaranya yang pertama, sebab adanya Penyuluh Agama Islam Non PNS adalah masih baru. Akan tetapi permasalahan tersebut tidak bisa digunakan sebagai alasan dari suatu program kerja itu gagal atau tidak mengalami perubahan, sebab semuanya kembali dari kinerja dari Penyuluh Agama Islam Non PNS itu sendiri terutama Bidang Perkawinan yang menjadi pokok penelitian peneliti.

Faktor yang kedua adalah individu masing-masing atau masyarakat binaannya. Meskipun Penyuluh sudah berusaha sekuat tenaga akan tetapi jika para pihak tetap tidak bisa didamaikan maka perpisahan itu akan tetap terjadi. Sebab Penyuluh tidak berhak memberikan suatu keputusan akhir, akan tetapi sesuai dengan tugas dan fungsi dari penyuluh itu sendiri adalah sebagai penengah atau penasihat terhadap permasalahan-permasalahan yang ada, mengenai hasil akhir atau keputusan kembali kepada para pihak yang bermasalah.

Dan faktor yang ketiga adalah minimnya pengetahuan agama masyarakat. Faktor ini adalah menjadi faktor yang utama, sebab jika masyarakat mengetahui ilmu agama dan mau mengaplikasikannya 
dalam kehidupan sehari-hari, maka rumah tangga yang mereka bangun akan sesuai dengan keinginannya yaitu $\neg$ menjadi rumah tangga yang sakinah mawaddah wa rahmah.

Tujuan Upaya Penyuluhan Pernikahan oleh Penyuluh Agama Islam Non PNS KUA Kecamatan Panceng.

Tujuan diadakan penyuluhan sangat jelas dipaparkan dalam bab sebelumnya yaitu membantu bagi calon pengantin lebih-lebih terhadap masyarakat yang sudah berumah tangga untuk mewujudkan rumah tangga yang sangat diimpikan serta membantu memecahkan permasalahan/konflik-konflik yang ada dalam rumah tangga, sehingga penyuluhan tersebut terarah dan sesuai dengan target yang diinginkan oleh pihak KUA.

Dalam memberikan penyuluhan, pihak KUA memiliki hal-hal yang menjadi penyebab mengapa diadakan bimbingan dan penyuluhan khususnya dalam bidang perkawinan, hal ini terkait dengan misi dari KUA Kecamatan Panceng itu sendiri yaitu meningkatkan pembinaan calon pengantin dan keluarga sakinah. Untuk itu maka peneliti menguraikan penyebab KUA Kecamatan Panceng melakukan bimbingan dan penyuluhan khususnya bidang perkawinan yang dipaparkan oleh narasumber melalui wawancara.

Menurut Bapak Syaiful Wahid sebagai kepala KUA Kecamatan Panceng menyimpulkan bahwa hal yang menyebabkan dilakukannya penyuluhan adalah :

1) Menyesuaikan dengan peraturan pemerintah yakni UU No. 1 Tahun 1974 dan KHI yakni batasan usia minimal seseorang melaksanakan pernikahan.

2) Mencegah pernikahan di bawah umur yang melanggar hukum yang berlaku di Indonesia.

3) Melestarikan pernikahan yang sakinah, mawaddah wa rahmah.

4) Menyeimbangkan, menserasikan, melaraskan pernikahan sesuai apa yang diharapkan berdasarkan kebutuhan lahir dan batin ${ }^{15}$.

Dari penjelasan di atas, maka menurut peneliti bahwa KUA Kecamatan Panceng dalam melakukan penyuluhan tersebut secara garis besar bertujuan untuk:

15 Syaiful Wahid, Wawancara, Kepala KUA Kecamatan Panceg (Panceng : Rabu, 18 Juli 2018). 
1) Agar Masyarakat taat terhadap Undang-Undang yang berlaku di Indonesia.

2) Mencegah terjadinya pernikahan di bawah umur yang berdampak pada meningkatkan angka perceraian.

3) Untuk menciptakan keluarga yang sakinah mawaddah wa rahmah sehingga seimbang, serasi dan selaras terhadap pernikahan yang sesuai dengan harapan secara lahir dan batin.

Untuk itu tujuan dari KUA Kecamatan Panceng selaras dengan tujuan dalam pernikahan yang diiginkan yakni sesuai dengan perintah Allah SWT memperoleh keturunan yang sah dalam masyarakat, dengan mendirikan rumah tangga yang damai dan teratur. Selain itu, ada pula pendapat yang mengatakan bahwa tujuan pernikahan dalam Islam selain untuk memenuhi kebutuhan hidup jasmani dan rohani manusia, juga sekaligus untuk membentuk keluarga dan memelihara serta meneruskan keturunan dalam menjalani hidupnya di dunia ini, juga mencegah perzinaan, agar tercipta ketenangan dan ketentraman jiwa bagi yang bersangkutan, ketentraman keluarga dan masyarakat ${ }^{16}$.

\section{Metode Penyuluhan Pernikahan oleh Penyuluh Agama Islam Non PNS KUA Kecamatan Panceng.}

Yang dimaksud dengan metode penyuluhan adalah cara penyampaian materi (isi pesan) penyuluhan agama oleh Penyuluh Agama kepada masyarakat baik secara langsung maupun tidak langsung agar mereka mengetahui, mau dan mampu menggunakan informasi keagaman dalam mewujudkan masyarakat taat beragama dan sejahtera lahir dan batin ${ }^{17}$.

Adapun metode-metode yang digunakan oleh Penyuluh Agama Islam Non PNS Bidang Perkawinan dalam melakukan tugasnya yaitu sesuai yang tertera dalam firman Allah SWT dalam Q.S. An-Nahl ayat 125, yang artinya:

"Serulah (manusia) kepada jalan Tuhan-mu dengan hikmah dan pelajaran yang baik dan bantahlah mereka dengan cara yang baik. Sesungguhnya Tuhanmu Dialah yang lebih mengetahui tentang siapa yang tersesat dari jalan-Nya dan Dialah yang lebih mengetahui orangorang yang mendapat petunjuk."

\footnotetext{
${ }^{16}$ Idris Ramulyo, Hukum Perkawinan Islam ,(Jakarta : Bumi Aksara, 1996), 26-27.

17 Kementerian Agama, Buku Pedoman Penyuluh Agama Islam Non PNS, (Surabaya : Kementerian Agama Provinsi Jawa Timur, 2017), 31.
} 
1) Bil Hikmah.

Yang dimaksud dengan hikmah di sini ialah perkataan yang tegas dan benar yang dapat membedakan antara yang hak dengan yang bathil. Metode ini diterapkan oleh Penyuluh Perkawinan KUA Kecamatan Panceng dengan cara melakukan safari dakwah ke desadesa wilayah Kecamatan Panceng, bakti sosial, pendampingan terhadap masalah ummat, dinamika kelompok dan ziarah napak tilas kesejarahan.

2) Mauidlotul Hasanah.

Metode ini diterapkan oleh Penyuluh Perkawinan KUA Kecamatan Panceng dengan cara melakukan penyuluhan ke kelompok binaannya, konsultasi, cerama agama dalam acara-acara, dan khutbah ${ }^{18}$.

3) Jaadilhum Billatii Hiya Ahsan.

Metode ini diterapkan oleh Penyuluh Perkawinan KUA Kecamatan Panceng dengan cara melakuakan ceramah dialogis, debat, diskusi, kajian/seminar/workshop, dan survey ke kelompok binaannya ${ }^{19}$.

Pedoman Kerja Penyuluhan Pernikahan oleh Penyuluh Agama Islam Non PNS KUA Kecamatan Panceng.

Penyuluh Agama Islam Non PNS khususnya bidang perkawinan selaku aparatur Kementerian Agama dalam melaksanakan tugasnya hendaknya selalu berorientasi pada pedoman kerja sebagai berikut :

1) Membuat program ditingkat Kecamatan bersama-sama dengan Penyuluh Agama Fungsional.

2) Membuat rencana kerja bulanan.

3) Menghubungi sasaran bingluh (dapat berupa lembaga formal maupun non formal) untuk menyepakati waktu dan tempat kegiatan bingluh.

4) Menyusun materi penyuluhan yang ada kaitannya dengan pernikahan.

5) Melaksanakan bingluh tatap muka dengan membawa surat tugas dan kelengkapan administrasi lainnya (surat keterangan telah memberikan bingluh dari penyelenggara apabila telah melaksanakan

\footnotetext{
${ }^{18}$ M. Zakaria, Wawancara, Penyuluh Agama Islam Non PNS Bidang Perkawinan dan Keluarga Sakinah (Panceng : Selasa, 17 Juli 2018).

${ }^{19}$ M. Zakaria, Wawancara, Penyuluh Agama Islam Non PNS Bidang Perkawinan dan Keluarga Sakinah (Panceng : Senin, 16 Juli 2018).
} 
kegiatan bingluh, absensi peserta penyuluhan, materi dan media yang digunakan dalam proses bingluh).

6) Membuat laporan mingguan pelaksanaan bingluh.

7) Membuat evaluasi pelaksanaan bingluh bulanan.

8) Melaporkan semua aktivitas kerja sebagai Penyuluh Agama Islam Non PNS pada setiap bulannya kepada Kasie Penais/Bimas/Binsyar sebagai pejabat pemberi tugas ${ }^{20}$.

Dari poin-poin yang sudah tertera di atas, peneliti menemukan suatu keganjalan pada waktu melakukan observasi di lapangan. Keganjalan tersebut adalah mengenai sistem kerja dari Penyuluh Agama Islam Non PNS yang ada di KUA Kecamatan Panceng yaitu menggunakan sistem piket. Dalam sehari ada dua Penyuluh Agama Islam Non PNS yang wajib berada di kantor dan untuk yang lainnya menyebar ke daerah binaannya masig-masing. Akan tetapi, kebanyakan Penyuluh Agama Islam Non PNS yang mendapatkan piket masuk kantor tidak mengikuti jam kerja yang sudah ditentukan oleh kantor, misalnya pulang terlebih dahulu dari pada pegawai-pegawai lainnya. Hal itu disebabkan karena ada kesibukan yang tidak bisa ditinggalkan atau tidak ada tugas yang dikerjakan. Menurut peneliti pribadi, alangkah lebih baiknya jika Penyuluh Agama Islam Non PNS tetap ikut jam kantor, sebab bagaimanapun juga itu adalah suatu kewajiban.

Pelaporan, Monitoring dan Evaluasi Kinerja Penyuluh Agama Islam Non PNS Bidang Perkawinan.

Pelaporan adalah bukti pertanggung jawaban kinerja secara tertulis yang dibuat oleh Penyuluh Agama Islam Non PNS dan dipertanggung jawabkan kepada atasan langsung, dalam hal ini kepala KUA Kecamatan, dengan tembusan kepada Ketua Pokja Penyuluh. Selanjutnya secara berjenjang Kepala KUA menyampaikan rekapitulasi laporan kepada Kepala Kemenag Kab/Kota, untuk diteruskan kepada Kepala Kanwil Kemenag Provinsi, dan oleh Kepala Bidang yang menangani penyuluh agama dilaporkan kepada Dirjen Bimas Islam melalui Direktur Penerangan Agama Islam ${ }^{21}$.

Penyuluh Agama Islam Non PNS dari segala bidang termasuk bidang perkawinan dan keluarga sakinah harus membuat laporan kegiatan dari

${ }^{20}$ Abdullah Hanif, Wawancara, Penyuluh Agama Islam Non PNS Bidang Perkawinan dan Keluarga Sakinah (Panceng: Rabu, 18 Juli 2018).

${ }^{21}$ M. Zakaria, Wawancara, Penyuluh Agama Islam Non PNS Bidang Perkawinan dan Keluarga Sakinah (Panceng : Rabu, 18 Juli 2018). 
bimbingan dan penyuluhan penyuluhan tatap muka yang dilaksanakan. Laporan tersebut mencakup antara lain :

1) Rencana kerja bulanan;

2) Surat keterangan telah memberikan bingluh dari penyelenggara;

3) Absensi peserta penuyuluhan;

4) Materi dan media bingluh;

5) Laporan mingguan pelaksanaan bingluh;

6) Evaluasi pelaksanaan bingluh bulanan;

7) Surat pernyataan melaksanakan bimbingan dan penyuluhan Agama Islam pada bidangnya masing-masing 22 .

Direktorat Penerangan Agama Islam melaksanakan monitoring dan evaluasi kegiatan penyuluhan yang dilakukan oleh Penyuluh Agama Islam Non PNS di Provinsi dan Kabupaten/Kota secara periodik.

Sedangkan untuk evaluasi terhadap kinerja Penyuluh Agama Islam Non PNS dilakukan setiap tahun. Hasil penilaian kinerja selama 1 (satu) tahun dijadikan dasar dalam melakukan Pergantian Antar Waktu (PAW) bagi Penyuluh Agama Islam Non PNS yang berkinerja buruk.

Kendala yang Dihadapi oleh Penyuluh Agama Islam Non PNS Kecamatan Panceng Bidang Perkawinan dalam Melakukan Proses Penyuluhan.

Sebuah program tidak terlepas dari faktor pendukung dan faktor penghambat. Begitu pula dengan program yang dimiliki dan sudah dirancang oleh KUA Kecamatan Panceng khususnya Penyuluh Agama Islam Non PNS bidang perkawinan dalam menjalankan misinya yaitu melakukan penyuluhan ke daerah binaannya tentang pentingnya membina keluarga yang sakinah.

Hambatan sekecil apapun bentuknya yang ada dalam suatu organisasi, pasti akan mempengaruhi serta merugikan organisasi tersebut karena pelaksanaan kegiatan dalam rangka pencapaian tujuan organisasi akan terhambat. Mengakibatkan gagalnya pencapaian tujuan yang telah ditetapkan dalam dasar-dasar keorganisasiannya.

Berdasarkan pengumpulan data yang peneliti lakukan melalui wawancara, ada beberapa hambatan yang dihadapi oleh KUA Kecamatan Panceng dalam melaksanakan bimbingan dan penyuluhan pernikahan. Faktor-faktor tersebut diantaranya :

22 Kementerian Agama, Buku Pedoman Penyuluh Agama Islam Non PNS, (Surabaya : Kementerian Agama Provinsi Jawa Timur, 2017), 38. 
a. Faktor Kendala Prespektif Masyarakat Binaan.

1) Fasilitas/sarana dan prasarana.

Masyarakat banyak yang bosan ketika mendapatkan materi sebab tidak ada media elektronik seperti LCD Projector yang dapat memberikan suasana yang berbeda. Terkadang juga sound sistem yang kurang, hal ini mengakibatkan peserta penyuluhan kurang dapat mendengarkan materi dengan baik ${ }^{23}$.

2) Keterbatasan waktu.

Proses penyuluhan yang dilakukan rata-rata hanya satu jam dalam sekali pertemuan, hal ini menyebabkan terbatasnya materi yang diuraikan dan kurangnya kesempatan bagi peserta untuk berdialog lebih banyak ${ }^{24}$.

b. Faktor Kendala Prespektif Penyuluh.

1) Dana penyuluhan

Dana merupakan suatu yang sangat vital dalam melakukan kegiatan apapun. Dengan adanya dana segala program kegiatan akan mudah tercapai sesuai keinginan. Akan tetapi berbeda dengan yang dialami oleh Penyuluh Agama Islam Non PNS di KUA Kecamatan Panceng ini, dalam melaksanakan penyuluhan tidak ada dana sekali untuk menopang suksesnya program. Akan tetapi para penyuluh membuat uang kas sendiri yang kemudian uang kas tadi digunakan untuk membeli segala hal yang dibutuhkan dalam proses penyuluhan, seperti konsumsi peserta, sewa sound system, dll25.

2) Kurangnya disiplin peserta.

Banyak peserta yang sering kali datang terlambat sehingga materi yang diterima menjadi tidak lengkap.

3) Sarana dan prasarana.

Sarana dan prasarana sangat berpengaruh dalam melakukan proses penyuluhan, sebab dengan adanya sarana yang lengkap maka proses penyuluhan akan tidak membosankan bagi masyarakat dan penyuluh dapat mengembangkan metode-

\footnotetext{
${ }^{23}$ Siti Maslahah, Wawancara, Masyarakat Kelompok Binaan Penyuluh Agama Islam Non PNS Bidang Perkawinan dan Keluarga Sakinah, (Panceng : Selasa, 17 Juli 2018).

${ }_{24}$ M. Qomari, Wawancara, Masyarakat Kelompok Binaan Penyuluh Agama Islam Non PNS Bidang Perkawinan dan Keluarga Sakinah (Panceng : Selasa, 17 Juli 2018).

${ }^{25}$ M. Zakaria, Wawancara, Penyuluh Agama Islam Non PNS Bidang Perkawinan dan Keluarga Sakinah, (Panceng : Senin, 16 Juli 2018).
} 
metode penyampaian materi. Misalnya LCD Projector, alat tersebut dapat membantu dalam penyampaian materi agar masyarakat tidak bosan.

4) Keterbatasan ruang bimbingan di KUA Panceng.

Kurang luasnya ruang bimbingan sehingga peserta yang mengikuti bimbingan sering kali tidak mendapatkan tempat duduk di dalam ruangan dan sampai keluar ruangan. Sehingga mengakibatkan kurangnya konsentrasi peserta terhadap materi yang disampaikan ${ }^{26}$.

5) Kurangnya tenaga Sumber Daya Manusia (SDM) yang bekerja di Kantor Urusan Agama (KUA).

Khusunya Penyuluh Agama Islam Non PNS yang hanya berjumlah 11 orang yang mana dari 11 orang tersebut dibagi lagi menjadi 8 bidang. Jumlah tersebut sangat sedikit disebabkan jumlah desa yang ada di Kecamatan Panceng sangatlah banyak yaitu 14 desa, hal ini mengakibatkan kinerja dari penyuluh sendiri kurang optimal sebab terkadang ada desa yang jarang didatangi. Harapan ke depan dari KUA adalah setiap desa nantinya akan disebarkan penyuluh-penyuluh ${ }^{27}$.

6) Hubungan Sosial.

Sesuai hasil wawancara peneliti kepada narasumber bahwasannya tidak semua masyarakat mau diajak untuk berbincang-bincang. Hal itu disebabkan karena pola fikir masyarakat yang tidak sama. ${ }^{28}$

\section{Penutup}

Peran yang dilakukan oleh Penyuluh Agama Islam Non PNS Bidang Perkawinan KUA Kecamatan Panceng memiliki 3 (tiga) program dalam menjalankan kewajibannya, yaitu :

- Memberi pembekalan kepada suscatin yakni khusus untuk calon pengantin yang sudah mendaftarkan dirinya di KUA yang berkehendak ingin melaksanakan pernikahan dan sebelumnya suscatin ini diberi pembekalan oleh BP4.

\footnotetext{
${ }^{26}$ M. Zakaria, Wawancara, Penyuluh Agama Islam Non PNS Bidang Perkawinan dan Keluarga Sakinah (Panceng : Senin, 16 Juli 2018).

27 Abdullah Hanif, Wawancara, Penyuluh Agama Islam Non PNS Bidang Perkawinan dan Keluarga Sakinah (Panceng : Senin, 16 Juli 2018).

${ }^{28}$ M. Zakaria, Wawancara, Penyuluh Agama Islam Non PNS Bidang Perkawinan dan Keluarga Sakinah (Panceng : Selasa, 24 Juli 2018
} 
- Memberi pembekalan pra nikah yakni ditujukan kepada semua kalangan yang berkehendak maupun yang belum berkehendak untuk melakukan pernikahan.

- Memberi bimbingan dan penyuluhan kepada masyarakat yang ada di desa-desa wilayah Kecamatan Panceng melalui kelompok binaanbinaan atau majlis ta'lim tentang kiat-kiat membentuk keluarga sakinah.

Kendala yang dihadapi oleh Penyuluh Agama Islam Non PNS Bidang Perkawinan KUA Kecamatan Panceng dalam menjalankan tugasnya adalah :

a. Faktor Kendala Prespektif Masyarakat Binaan :

1) Fasilitas/sarana dan prasarana.

2) Keterbatasan waktu.

b. Faktor Kendala Prespektif Penyuluh :

1) Dana penyuluhan.

2) Kurangnya disiplin peserta.

3) Sarana dan prasarana.

4) Keterbatasan ruang bimbingan di KUA Panceng.

5) Kurangnya tenaga Sumber Daya Manusia (SDM) yang bekerja di Kantor Urusan Agama (KUA).

6) Hubungan Sosial.

\section{Daftar Pustaka}

Undang-Undang Nomor 1 Tahun 1974 Tentang Perkawinan

PMA No. 34 Tahun 2016 Tentang Organisasi dan Tata Kerja Kantor Urusan Agama Kecamatan.

Abdul Manan. Aneka Masalah Hukum Perdata Islam di Indonesia. Jakarta: Kencana, 2006.

Abdul Syukur Al-Azizi. Sakinah Mawaddah wa Rahmah Tuntunan Lengkap Menggapai Baiti Jannati di dalam Rumah. Yogyakarta: Diva Press, 2017.

Ahmad Rafie Baihaqy. Membangun Surga Rumah Tangga. Surabaya: Gitamedia Press, 2006.

Amir Syarifuddin. Hukum Perkawinan di Indonesia antara Fiqih Munakahat dengan Undang-Undang Perkawinan. Jakarta: Kencana, 2006.

Darwan. Pengantar Bimbingan Konseling. Jakarta: Rineka Cipta, 2010.

Depag, Buku Panduan Pelaksanaan Tugas Penyuluhan Agama. Jakarta: Depag, 2003.

Depag. Panduan Tugas Operasional Penyuluhan Agama Islam, Jakarta: Depag, 2004. 
E Kristi Poerwandari. Pendekatan Kwalitatif dalam penelitian Psikologi. Jakarta: Lembaga Pengembangan Sarana Pengukuran dan Pendidikan Psikologi UI, 1983.

Harun Nasution. Islam Rasional; Gagasan dan Pemikiran. Bandung: Mizan, 1998.

Nawari Ismail. Metode Penelitian untuk Studi Islam. Yogyakarta: Samudra Biru, 2010.

Rahmat Hakim. Hukum Perkawinan Islam, Bandung: Pustaka Setia, 2000.

Slamet Abidin. Fiqh Munakahat 1. Bandung: Pustaka Setia, 1999.

Sulaiman Al-Mufarraj. Bekal Pernikahan; Hukum, Tradisi, Hikmah, Kisah, Syair, Wasiat, Kata Mutiara. Jakarta: Qisthi Press, 2003.

Tihami. Fikih Munakahat Kajian Fikih Nikah Lengkap. t.p. : t.t.

Wahbah Az-Zuhaili. Al-Figh Al-Islami Wa Adillatuhu, Jilid 9. Beirut: Dar AlFiqr, 1989.

WJS. Poerwadarminto. Kamus Umum Bahasa Indonesia. Jakarta: Balai Pustaka, 1995.

Wawancara Abdullah Hanif, Penyuluh Agama Islam Non PNS Bidang Perkawinan dan Keluarga Sakinah.

Wawancara M. Zakaria, Penyuluh Agama Islam Non PNS Bidang Perkawinan dan Keluarga Sakinah.

Wawancara M. Qomari, Masyarakat Kelompok Binaan Penyuluh Agama Islam Non PNS Bidang Perkawinan dan Keluarga Sakinah.

Wawancara Siti Maslahah, Masyarakat Kelompok Binaan Penyuluh Agama Islam Non PNS Bidang Perkawinan dan Keluarga Sakinah. 